\title{
Appendix: Residential Segregation by Skin Color: Brazil Revisited
}

Rubia da Rocha Valente

Brian J. L. Berry

Table 4: Index of Dissimilarity for Specific Cities by Income Group - 2010.

\begin{tabular}{|c|c|c|c|}
\hline \multirow[b]{2}{*}{$\begin{array}{l}\text { Metropolitan area and income } \\
\text { groups (number of minimum } \\
\text { wages) }\end{array}$} & \multicolumn{3}{|c|}{2010} \\
\hline & $\begin{array}{l}\text { White } \\
\text { vs. } \\
\text { Black }\end{array}$ & $\begin{array}{l}\text { White } \\
\text { vs. } \\
\text { Brown }\end{array}$ & $\begin{array}{l}\text { Brown } \\
\text { vs. } \\
\text { nBlack }\end{array}$ \\
\hline \multicolumn{4}{|c|}{ North } \\
\hline \multicolumn{4}{|l|}{ Manaus } \\
\hline less than 1 & .112 & .077 & .097 \\
\hline 1 to 2 & .144 & .089 & .107 \\
\hline 2 to 3 & .193 & .120 & .125 \\
\hline 3 to 5 & .205 & .154 & .161 \\
\hline 5 to 10 & .272 & .171 & .173 \\
\hline more than 10 & ---- & .138 & ---- \\
\hline \multicolumn{4}{|l|}{ Belém } \\
\hline less than 1 & .099 & .075 & .065 \\
\hline 1 to 2 & .152 & .101 & .073 \\
\hline 2 to 3 & .202 & .135 & .097 \\
\hline 3 to 5 & .238 & .140 & .119 \\
\hline 5 to 10 & .242 & .150 & .136 \\
\hline more than 10 & .254 & .140 & .159 \\
\hline \multicolumn{4}{|l|}{ Macapá } \\
\hline less than 1 & .135 & .063 & .128 \\
\hline 1 to 2 & .139 & .078 & .106 \\
\hline 2 to 3 & .139 & .080 & .119 \\
\hline 3 to 5 & .149 & .106 & .113 \\
\hline 5 to 10 & .196 & .134 & .151 \\
\hline more than 10 & ----- & .150 & ---- \\
\hline \multicolumn{4}{|l|}{ Northeast } \\
\hline \multicolumn{4}{|l|}{ Recife } \\
\hline less than 1 & .124 & .085 & .093 \\
\hline 1 to 2 & .173 & .124 & .093 \\
\hline 2 to 3 & .254 & .176 & .124 \\
\hline 3 to 5 & .315 & .197 & .160 \\
\hline 5 to 10 & .331 & .175 & .195 \\
\hline more than 10 & ----- & .118 & ----- \\
\hline \multicolumn{4}{|l|}{ Salvador* } \\
\hline less than 1 & .051 & .062 & .030 \\
\hline 1 to 2 & .155 & 137 & .032 \\
\hline 2 to 3 & .293 & .197 & .102 \\
\hline 3 to 5 & .332 & .189 & .148 \\
\hline 5 to 10 & .326 & 149 & .180 \\
\hline more than 10 & .276 & .103 & .173 \\
\hline \multicolumn{4}{|l|}{ Fortaleza } \\
\hline less than 1 & .156 & .091 & .121 \\
\hline 1 to 2 & .171 & .108 & .109 \\
\hline 2 to 3 & .252 & .138 & .166 \\
\hline 3 to 5 & .309 & .158 & .206 \\
\hline 5 to 10 & .376 & .156 & .270 \\
\hline more than 10 & ----- & .122 & ---- \\
\hline
\end{tabular}

*Data for Salvador, Goiânia, and Brasília were only available at the sub-district level, the remaining cities’ dissimilarity indexes were calculated at the neighborhood (bairros) level. Note that since not all cities have data for all bairros, we used the data that was made available by IBGE; the list of bairros can be found here:

http: //www.sidra.ibge.gov.br/bda/tabela, Table 1385. 
Table 5: Index of Dissimilarity for Specific Cities by Income Group Cont. — 2010.

\begin{tabular}{|c|c|c|c|}
\hline \multirow[b]{2}{*}{$\begin{array}{l}\text { Metropolitan area and income } \\
\text { groups (number of minimum } \\
\text { wages) }\end{array}$} & \multicolumn{3}{|c|}{2010} \\
\hline & $\begin{array}{l}\text { White } \\
\text { vs. } \\
\text { Black }\end{array}$ & $\begin{array}{l}\text { White } \\
\text { vs. } \\
\text { Brown }\end{array}$ & $\begin{array}{l}\text { Brown } \\
\text { vs. } \\
\text { nBlack }\end{array}$ \\
\hline Northeast & .364 & .321 & .269 \\
\hline \multicolumn{4}{|l|}{ João Pessoa } \\
\hline less than 1 & .129 & .090 & .107 \\
\hline 1 to 2 & .197 & .123 & .108 \\
\hline 2 to 3 & .273 & 147 & .166 \\
\hline 3 to 5 & .285 & .147 & .183 \\
\hline 5 to 10 & .313 & .131 & .222 \\
\hline more than 10 & ---- & .108 & ---- \\
\hline \multicolumn{4}{|l|}{ Natal } \\
\hline less than 1 & .104 & .086 & .094 \\
\hline 1 to 2 & .166 & .133 & .081 \\
\hline 2 to 3 & .217 & .145 & .119 \\
\hline 3 to 5 & .200 & .153 & .103 \\
\hline 5 to 10 & .229 & .113 & .157 \\
\hline more than 10 & .252 & .139 & .171 \\
\hline \multicolumn{4}{|l|}{ Teresina } \\
\hline less than 1 & .153 & .102 & .088 \\
\hline 1 to 2 & .194 & .117 & .106 \\
\hline 2 to 3 & .257 & .148 & .164 \\
\hline 3 to 5 & .299 & .160 & .203 \\
\hline 5 to 10 & .332 & .149 & .229 \\
\hline more than 10 & ----- & .143 & ----- \\
\hline \multicolumn{4}{|l|}{ Maceio } \\
\hline less than 1 & .098 & .066 & .073 \\
\hline 1 to 2 & .150 & .116 & .074 \\
\hline 2 to 3 & .201 & .154 & .112 \\
\hline 3 to 5 & .270 & .158 & .158 \\
\hline 5 to 10 & .319 & .171 & .199 \\
\hline more than 10 & ----- & .165 & ---- \\
\hline \multicolumn{4}{|l|}{ Aracaju } \\
\hline less than 1 & .110 & .087 & .068 \\
\hline 1 to 2 & .190 & .118 & .092 \\
\hline 2 to 3 & .220 & .152 & .103 \\
\hline 3 to 5 & .253 & .152 & .125 \\
\hline 5 to 10 & .302 & .150 & .186 \\
\hline more than 10 & .306 & .159 & .196 \\
\hline \multicolumn{4}{|l|}{ Feira de Santana } \\
\hline less than 1 & .153 & .093 & .078 \\
\hline 1 to 2 & .169 & .085 & .098 \\
\hline 2 to 3 & .203 & .119 & .120 \\
\hline 3 to 5 & .221 & .104 & .151 \\
\hline 5 to 10 & .288 & .136 & .202 \\
\hline more than 10 & ----- & .135 & ----- \\
\hline
\end{tabular}


Table 6: Index of Dissimilarity for Specific Cities by Income Group Cont. — 2010.

\begin{tabular}{|c|c|c|c|}
\hline \multirow[b]{2}{*}{$\begin{array}{l}\text { Metropolitan area and income } \\
\text { groups (number of minimum } \\
\text { wages) }\end{array}$} & \multicolumn{3}{|c|}{2010} \\
\hline & $\begin{array}{l}\text { White } \\
\text { vs. } \\
\text { Black }\end{array}$ & $\begin{array}{l}\text { White } \\
\text { vs. } \\
\text { Brown }\end{array}$ & $\begin{array}{l}\text { Brown } \\
\text { vs. } \\
\text { nBlack }\end{array}$ \\
\hline \multicolumn{4}{|c|}{ Northeast* } \\
\hline \multicolumn{4}{|l|}{ Campina Grande } \\
\hline less than 1 & .181 & .083 & .144 \\
\hline 1 to 2 & .166 & .121 & .103 \\
\hline 2 to 3 & .204 & .130 & .133 \\
\hline 3 to 5 & .330 & .148 & .226 \\
\hline 5 to 10 & ----- & .142 & ----- \\
\hline more than 10 & -.--- & .162 & ----- \\
\hline \multicolumn{4}{|l|}{ Central-West } \\
\hline \multicolumn{4}{|l|}{ Vale do Rio Cuiabá } \\
\hline less than 1 & .162 & .116 & .098 \\
\hline 1 to 2 & .187 & .136 & .097 \\
\hline 2 to 3 & .250 & .173 & .130 \\
\hline 3 to 5 & .296 & .194 & .152 \\
\hline 5 to 10 & .319 & .182 & .200 \\
\hline more than 10 & ----- & .185 & ----- \\
\hline \multicolumn{4}{|l|}{ Goiânia } \\
\hline less than 1 & .135 & .109 & .068 \\
\hline 1 to 2 & .151 & .114 & .079 \\
\hline 2 to 3 & .213 & .142 & .096 \\
\hline 3 to 5 & .237 & .165 & .122 \\
\hline 5 to 10 & .279 & .162 & .145 \\
\hline more than 10 & .264 & .145 & .173 \\
\hline \multicolumn{4}{|l|}{ Brasília } \\
\hline less than 1 & .074 & .062 & .024 \\
\hline 1 to 2 & .103 & .090 & .033 \\
\hline 2 to 3 & .158 & .131 & .047 \\
\hline 3 to 5 & .199 & .140 & .065 \\
\hline 5 to 10 & .233 & .195 & .061 \\
\hline more than 10 & .237 & .157 & .086 \\
\hline \multicolumn{4}{|l|}{ Southeast } \\
\hline \multicolumn{4}{|l|}{ Rio de Janeiro } \\
\hline less than 1 & .138 & .124 & .093 \\
\hline 1 to 2 & .166 & .167 & .075 \\
\hline 2 to 3 & .253 & .225 & .076 \\
\hline 3 to 5 & .326 & .269 & .094 \\
\hline 5 to 10 & .374 & .287 & .120 \\
\hline more than 10 & .349 & .259 & .135 \\
\hline \multicolumn{4}{|l|}{ Belo Horizonte } \\
\hline less than 1 & .225 & .177 & .101 \\
\hline 1 to 2 & .268 & .198 & .109 \\
\hline 2 to 3 & .339 & .233 & .156 \\
\hline 3 to 5 & .373 & .248 & .177 \\
\hline 5 to 10 & .411 & .262 & .210 \\
\hline more than 10 & ---- & .267 & ---- \\
\hline
\end{tabular}

*No income data was available for Itabuna and São Luis. 
Table 7: Index of Dissimilarity for Specific Cities by Income Group Cont. — 2010

\section{0}

\begin{tabular}{|c|c|c|c|}
\hline $\begin{array}{l}\text { Metropolitan area and income } \\
\text { groups (number of minimum } \\
\text { wages) }\end{array}$ & $\begin{array}{l}\text { White } \\
\text { vs. } \\
\text { Black }\end{array}$ & $\begin{array}{l}\text { e White } \\
\text { vs. } \\
\text { Brown }\end{array}$ & $\begin{array}{l}\text { Brown } \\
\text { vs. } \\
\text { nBlack }\end{array}$ \\
\hline \multicolumn{4}{|c|}{ Southeast } \\
\hline \multicolumn{4}{|l|}{ Vitoria } \\
\hline less than 1 & .261 & .208 & .118 \\
\hline 1 to 2 & .316 & .232 & .147 \\
\hline 2 to 3 & .332 & .206 & .168 \\
\hline 3 to 5 & .305 & .199 & .176 \\
\hline 5 to 10 & .310 & .177 & .174 \\
\hline more than 10 & ----- & .163 & ---- \\
\hline \multicolumn{4}{|l|}{ Barra MansalVolta Redonda } \\
\hline less than 1 & .162 & .128 & .102 \\
\hline 1 to 2 & .194 & .154 & .112 \\
\hline 2 to 3 & .266 & .198 & .155 \\
\hline 3 to 5 & .332 & .246 & .214 \\
\hline 5 to 10 & --- & .278 & 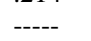 \\
\hline more than 10 & ----- & ---- & ----- \\
\hline \multicolumn{4}{|l|}{ Juiz de Fora } \\
\hline less than 1 & .200 & .133 & .108 \\
\hline 1 to 2 & .249 & .185 & .114 \\
\hline 2 to 3 & .345 & .230 & .161 \\
\hline 3 to 5 & .392 & .240 & .216 \\
\hline 5 to 10 & .336 & .222 & .237 \\
\hline more than 10 & ---- & .279 & ----- \\
\hline \multicolumn{4}{|l|}{ Ipatinga } \\
\hline less than 1 & .074 & .073 & .064 \\
\hline 1 to 2 & .120 & .097 & .064 \\
\hline 2 to 3 & .220 & .125 & .118 \\
\hline 3 to 5 & .225 & .157 & .112 \\
\hline 5 to 10 & .281 & .201 & .212 \\
\hline more than 10 & ----- & .232 & ----- \\
\hline \multicolumn{4}{|l|}{ Uberlandia } \\
\hline less than 1 & .160 & .151 & .087 \\
\hline 1 to 2 & .190 & .162 & .072 \\
\hline 2 to 3 & .235 & .188 & .087 \\
\hline 3 to 5 & .292 & .193 & .138 \\
\hline 5 to 10 & .323 & .193 & .224 \\
\hline more than 10 & ---- & .227 & ---- \\
\hline \multicolumn{4}{|l|}{ Campos } \\
\hline less than 1 & .227 & .166 & .111 \\
\hline 1 to 2 & .268 & .198 & .150 \\
\hline 2 to 3 & .313 & .209 & .199 \\
\hline 3 to 5 & .321 & .202 & .221 \\
\hline 5 to 10 & ---- & .212 & ---- \\
\hline more than 10 & ----- & .236 & ----- \\
\hline
\end{tabular}


Table 8: Index of Dissimilarity for Specific Cities by Income Group Cont. — 2010.

\begin{tabular}{|c|c|c|c|}
\hline \multirow[b]{2}{*}{$\begin{array}{l}\text { Metropolitan area and income } \\
\text { groups (number of minimum } \\
\text { wages) }\end{array}$} & \multicolumn{3}{|c|}{2010} \\
\hline & $\begin{array}{l}\text { White } \\
\text { vs. } \\
\text { Black }\end{array}$ & $\begin{array}{l}\text { White } \\
\text { vs. } \\
\text { Brown }\end{array}$ & $\begin{array}{l}\text { Brown } \\
\text { vs. } \\
\text { nBlack }\end{array}$ \\
\hline \multicolumn{4}{|c|}{ Southeast } \\
\hline \multicolumn{4}{|l|}{ São Paulo Capital } \\
\hline less than 1 & .167 & .175 & .070 \\
\hline 1 to 2 & .231 & .239 & .071 \\
\hline 2 to 3 & .283 & .292 & .101 \\
\hline 3 to 5 & .300 & .300 & .125 \\
\hline 5 to 10 & .344 & .309 & .169 \\
\hline more than 10 & ----- & .342 & ----- \\
\hline \multicolumn{4}{|l|}{ Santos } \\
\hline less than 1 & .202 & .202 & .086 \\
\hline 1 to 2 & .263 & .274 & .091 \\
\hline 2 to 3 & .304 & .324 & .125 \\
\hline 3 to 5 & .306 & .318 & .138 \\
\hline 5 to 10 & .314 & .308 & .183 \\
\hline more than 10 & ----- & .290 & ----- \\
\hline \multicolumn{4}{|l|}{ Campinas } \\
\hline less than 1 & .171 & .127 & .096 \\
\hline 1 to 2 & .210 & .163 & .102 \\
\hline 2 to 3 & .255 & .230 & .106 \\
\hline 3 to 5 & .321 & .277 & .163 \\
\hline 5 to 10 & .330 & .295 & .166 \\
\hline more than 10 & ----- & ----- & ----- \\
\hline \multicolumn{4}{|l|}{ São José dos Campos } \\
\hline less than 1 & .175 & .192 & .059 \\
\hline 1 to 2 & .170 & .200 & .059 \\
\hline 2 to 3 & .195 & .177 & .086 \\
\hline 3 to 5 & .263 & .209 & .106 \\
\hline 5 to 10 & .353 & .219 & .173 \\
\hline more than 10 & ----- & .187 & ---- \\
\hline \multicolumn{4}{|l|}{ Sorocaba (Tatui/Boituva)* } \\
\hline less than 1 & .234 & .255 & .181 \\
\hline 1 to 2 & .290 & .278 & .172 \\
\hline 2 to 3 & ----- & .309 & ----- \\
\hline 3 to 5 & ------ & ----- & ----- \\
\hline 5 to 10 & ----- & ----- & ----- \\
\hline more than 10 & ----- & ----- & ----- \\
\hline \multicolumn{4}{|l|}{ Ribeirão Preto } \\
\hline less than 1 & .184 & .179 & .084 \\
\hline 1 to 2 & .222 & .205 & .085 \\
\hline 2 to 3 & .267 & .252 & .100 \\
\hline 3 to 5 & .314 & .259 & .124 \\
\hline 5 to 10 & ----- & .288 & - \\
\hline more than 10 & ----- & ---- & ---- \\
\hline
\end{tabular}

*Not enough blacks and browns to compute indexes at the higher income categories. 
Table 9: Index of Dissimilarity for Specific Cities by Income Group Cont. — 2010.

\section{0}

\begin{tabular}{|c|c|c|c|}
\hline $\begin{array}{l}\text { Metropolitan area and income } \\
\text { groups (number of minimum } \\
\text { wages) }\end{array}$ & $\begin{array}{l}\text { White } \\
\text { vs. } \\
\text { Black }\end{array}$ & $\begin{array}{l}\text { White } \\
\text { vs. } \\
\text { Brown }\end{array}$ & $\begin{array}{l}\text { Brown } \\
\text { vs. } \\
\text { nBlack }\end{array}$ \\
\hline \multicolumn{4}{|c|}{ Southeast } \\
\hline \multicolumn{4}{|l|}{ Jundiai } \\
\hline less than 1 & .173 & .242 & .144 \\
\hline 1 to 2 & .178 & .224 & 137 \\
\hline 2 to 3 & .215 & 242 & 186 \\
\hline 3 to 5 & .252 & .233 & .183 \\
\hline 5 to 10 & .245 & .267 & .227 \\
\hline more than 10 & ---- & ----- & ----- \\
\hline \multicolumn{4}{|l|}{ South } \\
\hline \multicolumn{4}{|l|}{ Porto Alegre } \\
\hline less than 1 & .324 & .219 & .181 \\
\hline 1 to 2 & .308 & .216 & .168 \\
\hline 2 to 3 & .287 & .214 & .161 \\
\hline 3 to 5 & .282 & .224 & .157 \\
\hline 5 to 10 & .301 & .227 & .184 \\
\hline more than 10 & ---- & ----- & ----- \\
\hline \multicolumn{4}{|l|}{ Curitiba } \\
\hline less than 1 & .122 & .138 & .067 \\
\hline 1 to 2 & .161 & .174 & .071 \\
\hline 2 to 3 & .205 & .214 & .088 \\
\hline 3 to 5 & .254 & .213 & .114 \\
\hline 5 to 10 & .277 & 198 & .142 \\
\hline more than 10 & ---- & .222 & ---- \\
\hline \multicolumn{4}{|l|}{ Pelotas-Rio Grande } \\
\hline less than 1 & .138 & .126 & .106 \\
\hline 1 to 2 & .176 & .158 & .142 \\
\hline 2 to 3 & .186 & .171 & .116 \\
\hline 3 to 5 & .271 & .201 & .178 \\
\hline 5 to 10 & .352 & 260 & .226 \\
\hline more than 10 & ---- & ---- & ---- \\
\hline \multicolumn{4}{|l|}{ Florianópolis } \\
\hline less than 1 & .247 & .176 & .188 \\
\hline 1 to 2 & .189 & .148 & .182 \\
\hline 2 to 3 & .185 & .146 & .177 \\
\hline 3 to 5 & .249 & .171 & .223 \\
\hline 5 to 10 & .267 & .210 & .226 \\
\hline more than 10 & ---- & .203 & ---- \\
\hline \multicolumn{4}{|l|}{ Londrina } \\
\hline less than 1 & .144 & .149 & .089 \\
\hline 1 to 2 & .198 & .182 & .072 \\
\hline 2 to 3 & .325 & 238 & .141 \\
\hline 3 to 5 & .339 & .272 & .217 \\
\hline 5 to 10 & .375 & .231 & .230 \\
\hline more than 10 & ----- & .211 & ---- \\
\hline
\end{tabular}


Table 10: Index of Dissimilarity for Specific Cities by Income Group Cont. — 2010.

\begin{tabular}{|c|c|c|c|}
\hline \multirow[b]{2}{*}{$\begin{array}{l}\text { Metropolitan area and income } \\
\text { groups (number of minimum } \\
\text { wages) }\end{array}$} & \multicolumn{3}{|c|}{2010} \\
\hline & $\begin{array}{l}\text { White } \\
\text { vs. } \\
\text { Black }\end{array}$ & $\begin{array}{l}\text { White } \\
\text { vs. } \\
\text { Browl }\end{array}$ & $\begin{array}{l}\text { Brown } \\
\text { vs. } \\
\text { nBlack }\end{array}$ \\
\hline \multicolumn{4}{|c|}{ South } \\
\hline \multicolumn{4}{|l|}{ Joinville } \\
\hline less than 1 & .170 & 170 & 146 \\
\hline 1 to 2 & .162 & .150 & .138 \\
\hline 2 to 3 & 189 & .160 & .157 \\
\hline 3 to 5 & .181 & .175 & .187 \\
\hline 5 to 10 & .272 & .165 & .189 \\
\hline more than 10 & ----- & ----- & ----- \\
\hline \multicolumn{4}{|l|}{ Caxias do Sul } \\
\hline less than 1 & .196 & .199 & .162 \\
\hline 1 to 2 & .195 & .211 & .129 \\
\hline 2 to 3 & 196 & 199 & .162 \\
\hline 3 to 5 & .285 & .292 & .150 \\
\hline 5 to 10 & ----- & .242 & ----- \\
\hline more than 10 & ----- & ----- & ----- \\
\hline \multicolumn{4}{|l|}{ Combined Index* } \\
\hline less than 1 & .293 & .306 & .226 \\
\hline 1 to 2 & .326 & .357 & .202 \\
\hline 2 to 3 & .345 & .383 & .213 \\
\hline 3 to 5 & .376 & .410 & .247 \\
\hline 5 to 10 & .390 & .421 & .278 \\
\hline more than 10 & .379 & .425 & .303 \\
\hline
\end{tabular}

*The combined index refers to the pooled data for all metropolitan areas by income categories. Note that data for Itabina and São Luis was not available, and Salvador, Brasilia, Goiania and Pelotas-Rio Grande were not included in the combined index because they were at the sub-district level.

Note: Replication files are available here:

https://gitlab.com/rubiavalente/residential-segregation-in-brazil-2010 